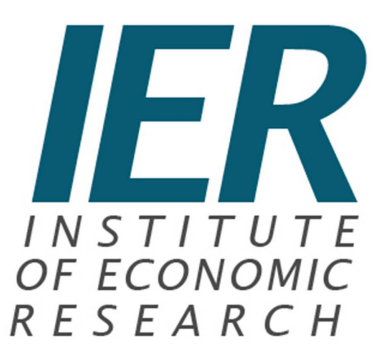

Institute of Economic Research Working Papers

No. 13/2014

\title{
Fiscal Contractions in Eurozone in the Years 1995-2013. Can Non-Keynesian Effects Be Helpful in Future Deleverage Process?
}

Adam P. Balcerzak, Michał Pietrzak, Elżbieta Rogalska

Toruń, Poland 2014

(C) Copyright: Creative Commons Attribution 3.0 License

The paper prepared for the $14^{\text {th }}$ Eurasia Business and Economics Society Conference October 23-25, 2014 Barcelona, Spain.

Published in: Mehmet Huseyin Bilgin, Hakan Danis, Ender Demir, Ugur Can (eds.). 2015. Business Challenges in the Changing Economic Landscape - Vol. 1. Proceedings of the 14th Eurasia Business and Economics Society. Heidelberg: Springer. ISBN 978-3-31922595-1.

Quoting:

Adam P. Balcerzak, Michał Bernard Pietrzak \& Elżbieta Rogalska (2015). Fiscal Contractions in Eurozone in the years 1995-2012: Can non-Keynesian effects be helpful in future deleverage process?. In: Mehmet Huseyin Bilgin, Hakan Danis, Ender Demir, Ugur Can (eds.). Business Challenges in the Changing Economic Landscape - Vol. 1. Proceedings of the 14th Eurasia Business and Economics Society. Heidelberg: Springer. pp. 483-496. 


\title{
Fiscal Contractions in Eurozone in the Years 1995-2013. Can Non-Keynesian Effects Be Helpful in Future Deleverage Process?
}

\author{
ADAM P. BALCERZAK \\ Department of Economics \\ Nicolaus Copernicus University \\ Poland \\ apb@umk.pl \\ MICHAŁ BERNARD PIETRZAK \\ Department of Econometrics and Statistics \\ Nicolaus Copernicus University \\ Poland \\ michal.pietrzak@umk.pl \\ ELŻBIETA ROGALSKA \\ Department of Microeconomics \\ University of Warmia and Mazury \\ Poland \\ e.rogalska@interia.pl
}

\begin{abstract}
Last global financial crisis has led to massive fiscal stimulation actions in most of developed countries which resulted in significant increase of their public debt. For many economists current level of debt in case of many highly developed countries is coming up to unsustainable level or at least level that has negative consequences on the long term growth. This can be also said about Eurozone or wider EU economies. This factors in near future will force many EU countries to adopt much stricter middle and long term fiscal policy that will be necessary for deleveraging process. In this context the aim of the research is to check whether can one find non-Keynesian effects of fiscal consolidations in Eurozone countries in last decade. If the answer is positive, then could these non-Keynesian effects be significant developing factor in case of Eurozone countries. The third scientific question concentrates on the ways the fiscal consolidations were implemented and the potential influence of consolidations strategies on short term growth. The research is based on European Commission and Eurostat fiscal and macroeconomic data for Eurozone countries for the years 1995-2013. In the research the econometric dynamic panel model based on the concept of conditional convergence was applied. As a complementary method qualitative analysis of cases of significant contractions was made with the concentration on the differences between expansionary thus non-Keynesian cases and conventional Keynesian cases of fiscal contractions. The research results give some arguments for existence of fiscal transitions channels leading to non-Keynesian effects of fiscal policy, which in the same time can be a factor of conditional convergence. Thus in case of proper construction of fiscal consolidations polices these factors can be helpful in future deleverage process.
\end{abstract}

Keywords: fiscal policy, fiscal consolidations, non-Keynesian effects, conditional convergence 


\section{Introduction}

The end of $X X^{\text {th }}$ century was a period when most academic economists and decision makers accepted the view that the anti-cyclical policy should be mostly based on the monetary tools. In that period many believed that principals of prudent fiscal policy should be concentrated on the middle and long term aims supporting long term growth. As it was stated by Martin Eichenbaum: "In sharp contrast to the views that prevailed in the early 1960's, there is now widespread agreement that countercyclical discretionally fiscal policy is neither desirable nor politically feasible. Practical debates around stabilization policy revolve almost exclusively around monetary policy" (Eichenbaum, 1997, p. 236). In that time a wide research on the possibility of non-Keynesian effects of fiscal consolidations was started (see: Gavazzi, Pagano 1990, pp. 82-92; Alesina, Ardagna 1998, pp. 489-545).

In the sphere of fiscal policy in European Union last decade of $X X^{\text {th }}$ and the beginning of $\mathrm{XXI}^{\text {th }}$ century were influenced with the process of Eurozone creation and the efforts to fulfill Maastricht Treaty criteria. As a result in that period a significant decrease of government debt for countries that created euro area was obtained. The average level of government consolidated gross debt for first eleven members of the Eurozone decreased form the level of $69 \%$ of their GDP in 1995 to 54\% in 2007 (Eurostat database 2014).

However, global financial crisis that started in the year 2008, at least in the sphere of fiscal policy practice of developed countries, has led to a serious change in the approach to fiscal policy. Most European countries implemented massive fiscal policy stimulation programs that in Keynesian way were supposed to increase aggregate demand and bring short term anticrisis effects. This resulted in significant increase of government debts in European Union that in longer term can become serious obstacle for growth. In case of mentioned eleven first members of euro area the average level of government consolidated gross debt rose form the mentioned $54 \%$ in 2007 to $89,2 \%$ in 2013. In case of the Eurozone (27 countries) this value rose from the average level of 58,9 in 2007 to $87,4 \%$ of GDP in 2013 (Eurostat Database 2014).

In this context three scientific questions are the base for that paper. First of all, the aim of the research is to check whether can one find non-Keynesian effects of fiscal consolidations in Eurozone countries in last two decades. If the answer is positive, then could these nonKeynesian effects be significant developing factor in case of Eurozone countries? The third scientific question concentrates on the ways the consolidations were implemented and the potential influence of consolidations strategies on short term growth.

In order to find the answer to the first two questions the hypothesis of conditional $\beta$ convergence for 11 countries that started euro area for the years 1995-2013 was tested. As the variables determining the output in the steady state the investments per capita and the government primary balance describing the fiscal policy were used. The verification of hypothesis of $\beta$-convergence process enables to identify the long term tendency of output per capita among analyzed countries. In the same time verification of the hypothesis enables to identify non-Keynesian effects of fiscal prudence as a positive influence of fiscal restrictive policy on the level of output per capita. The empirical part is based on the Eurostat database data. The data concerning primary balance was taken from European Commission report (2013).

The article consists of three parts. In the first one the theoretical background concerning the non-Keynesian effects is discussed. The second and third part have strictly empirical nature. The second part is devoted to econometric analysis of consequences of fiscal prudence. Here the econometric dynamic panel model based on the concept of conditional convergence was applied. In the third part qualitative analysis of cases of significant 
consolidations was made with the concentration on the differences between expansionary thus non-Keynesian cases and conventional Keynesian cases of fiscal contractions.

\section{Fiscal Consolidations as a Positive Supply Shock Supporting Convergence}

Based on the basic textbook approach in the long term prudent (defined as rather restrictive) fiscal policy is considered as a factor supporting capital accumulation and productive investments. Thus, it is improving long term growth and can be a factor supporting economic convergence. On the other hand, form the short term Keynesian perspective fiscal consolidations tend to negatively influence aggregate demand and with multiplier effects dampen current growth, whereas fiscal expansions in spite of the possibility of crowding out effects (Balcerzak, Rogalska 2014, s. 80-93) tend to support current activity of economy and short term growth.

However, the end of eighties of $X X^{\text {th }}$ century with the experiences of Denmark in the years 1983-84 and Ireland in the years 1987-89 showed the possibility of not standard short term effects of fiscal restrictions, where the improvement of government fiscal balance led to increase of aggregate demand and product. New research program concerning expansionary (non-Keynesian) effects of fiscal consolidations was started (Gavazzi, Pagano 1990, pp. 82-92).

The models explaining the transmission mechanisms of non-Keynesian effects of fiscal consolidations are usually classified to two groups. The first one attributes the nonKeynesian effects to the demand side of economy and the results of expectations change of private agents in the situation of uncertainty concerning their future tax burden (Rogalska 2012 , p. 5-22). This mechanism is based on the expectation of households that due to current fiscal consolidations the future tax burden will decrease, which is the source of wealth effect. As a result the households that tend to smooth their consumption during their lifespan can increase their current consumption, which under positive circumstances (for example determined by the relation between the agents maximizing their consumption during their whole lives and liquidity constrained agents depending on their current income) can offset the negative effects of decrease of government expenditures (Alesina, Ardagna 2009). In that context three factors tend to increase the possibility of non-Keynesian occurrence. First of all, the scale of consolidations must be big enough to convince the households that there is a real chance for lower tax burden in the future. The second condition is the credibility of fiscal authorities. The household must believe that the government is not going to change the prudent fiscal policy with the minor improvement of situations. In that context the third factor which is current budget situation can be also decisive. Some models predict that in case of very high and growing level of public debt when the household expect that the level of debt is not sustainable, it must result in inevitable and significant increase of taxes, the implementation of strict consolidations can be a reason for change of expectations (see Perotii 1999, pp. 1399-1436).

The second group of models concentrates on the supply side of economy and the positive influence of reducing government expenditures on the costs level and thus competitiveness of enterprises (Rzońca, Ciżkowicz 2005, pp. 7-10). In the literature there are many models concentrating on the supply side of economy and reactions of enterprises to fiscal adjustments. The most important determinant of results of fiscal consolidations is the composition of adjustment (Rzońca, Varoudakis 2007, p. 8; Alesina et all. 1999; Lane, Perotti 2001; Alesina, Ardagana, 1998, pp. 490-545, 2009). Alesina and Perotti (1997, pp. 921-939) were investigating supply side effects of fiscal adjustments in unionized economies with imperfect competition markets. In case of labor markets with strong unions, fiscal consolidations that were mainly based on income tax increases were resulting in increased pressure on wage rises, thus increasing costs of enterprises and diminishing their price competitiveness. In the end this can become additional negative supply shock that can 
threaten effectiveness of fiscal adjustment. On the other hand, the strategy based on public expenditures cuts in case of positive influence on enterprises price competitiveness can have offsite results. When the lower public expenditures are the result of wages cuts and lower employment in public sector, the lack of possibilities of earning and lower wages in public sector can decrease the wage pressure in private sector, which can influence positively enterprise profits and increase their investment capabilities. The final consequence of this mechanism can be higher international price competitiveness of enterprises and it can result in non-Keynesian results of fiscal consolidation (Alesina, Ardagana 2009, p. 4). Of course, the whole mechanism is quite complex and it depends on many factors such as the influence of export channel on the national economy, the ratio of labour costs to global costs of enterprises, the speed and rate of influence of positive supply shock in the sphere of labor costs.

Concentrating on the problem of relation of short term fiscal policy and middle or long term growth, thus the chances for obtaining the convergence process, the effectiveness of transmission mechanisms of the supply side models is crucial. In this context from the perspective of supply side economy, the basic role of government should be decreasing the price rigidity on the product markets and increasing elasticity of labor markets. When the markets are characterized with sufficient elasticity the export channel can be a factor increasing the chances for successful fiscal consolidations. Based on that approach, in case of short term fiscal policy consolidation actions should rather concentrate on the effort to reduce government expenditures than the programs of tax and revenue increases (see more Alesina, Ardagana 2009).

\section{Fiscal Prudence and Conditional Convergence - Econometric Analysis}

In order to verify the hypothesis of the paper the convergence analysis for the first 11 euro zone members was done. The parameters of the dynamic panel model for 1995-2013 were estimated, which enable to identify conditional $\beta$-convergence process. The convergence analysis framework has been widely discussed in the literature. The problems of absolute convergence, conditional $\beta$-converegence, $\sigma$-convergence, club-convergence, stochastic convergence and application of panel models or tools of spatial econometric for the convergence analysis were discussed by Baumol (1986), Barro and Sala-i-Martin (1991, 1992, 1995), Bond, Hoeffler, Tmple 2001, Casellie, Esquivela, Lefort 1996, Sala-I-Martin (1996a, 1996b), Mankiw, Romer, Weil (1992), Durlauf, Johnson (1995); Quah (1993a, 1993b, 1996a, 1996b), Bernard, Durlauf (1995), Evans, Karras (1996), Islam (1995), Caselli, Esquivel, Lefort (1996), Rey, Montouri (1999), Le Gallo, Ertur (2000), LeGallo (2001), Ciołek (2004), Arbia (2006).

The phenomena of $\beta$-convergence means that all the analyzed countries in the long term converge in terms of income per capita. In a given period that common income per capita is reached within the long term steady state. The convergence phenomena was enriched with conditional $\beta$-convergence where one assumes that every country tend to reach his own steady state. The income level in the steady state for every region is determined by economic process that characterize the fundamental conditions of economy such as the investment rate and depreciation, the demographic processes and population growth, the quality of human capital, and the technology (see. Mankiw et all. 1992; Levine and Renelt 1992). In case of $\beta$-convergence the countries can reach the same income level but only provided that they are similar in terms of economic variables that determine the output in the steady state.

The hypothesis of conditional $\beta$-convergence was tested by estimation of parameters of dynamic panel model (Baltagi 1995) that is described with the equation 3. The dependent variable was GDP per capita in purchasing power standards. The independent variable was the real investment per capita and the primary balance defined as government net lending or 
net borrowing excluding interest, which is variable that characterize the fiscal policy approach. The positive value of that variable is equivalent to government surplus whereas negative means the government deficit. In the context of the theoretical background described in section 2 of the paper that parameter $\alpha_{1}$ should be positive and statistically significant.

$$
\begin{aligned}
& \mathbf{Y}_{i t}^{*}=\beta_{0}-\beta_{1} \ln \mathbf{Y}_{i t-1}+\alpha_{1} \mathbf{X}_{1, i t}+\alpha_{2} \ln \mathbf{X}_{2, i t}+\boldsymbol{\eta}_{i}+\boldsymbol{\varepsilon}_{i t} \\
& \mathbf{Y}_{i t}^{*}=\ln \left(\mathbf{Y}_{i t} / \mathbf{Y}_{i t-1}\right) \\
& \ln \mathbf{Y}_{i t}=\beta_{0}+\gamma \ln \mathbf{Y}_{i t-1}+\alpha_{1} \mathbf{X}_{1, i t}+\alpha_{2} \ln \mathbf{X}_{2, i t}+\boldsymbol{\eta}_{i}+\boldsymbol{\varepsilon}_{i t} \\
& \gamma=\left(1-\beta_{1}\right)
\end{aligned}
$$

Where: $\mathbf{Y}_{i t}$ is the vector of GDP per capita, $\mathbf{Y}_{i t}^{*}$ is the vector of the rate of growth of GDP per capita, $\mathbf{X}_{1}$ is the vector of primary balance describing fiscal prudence, vector $\mathbf{X}_{2}$ describe the investment per capita, $\beta_{0}, \beta_{1}, \alpha_{1}, \alpha_{2}, \gamma$ are the structural parameters of the model ${ }^{\eta_{i}}$ is the vector of individual effects of a panel model), $a^{\boldsymbol{\varepsilon}_{i t}}$ is the vector of disturbances. All the variables are determined for i-country in the period t. Variables $X_{1}$ and $X_{2}$ are the potential variables that determine the output in the steady state.

Obtaining the statistically significant value of parameter $\gamma$ that is lover than 1 positively verifies the hypothesis of conditional $\beta$-convergence for the analyzed countries. The convergence process will occur provided that all the countries will be characterized with similar level of variables that determine the output in the steady state. The lower value of $\gamma$ (higher positive value of parameter $\beta 1$ ) the faster convergence process occur. The identification of convergence process enables to answer the question concerning the economic variables that determine the possibility of convergence process between a given group of countries. Additionally the estimated value of parameter $\gamma$ enables to estimate average annual speed of convergence and the time that is needed for reaching the half the distance between the starting level of output and the output in the steady state (see. Barro, Sala-i-Martin 1995, Ciołek 2004). The average speed of convergence ${ }^{2}$ is described with the equation (5):

$$
b=-\ln (\gamma) / T,
$$

and the time that is needed for reaching the half way between the average starting level of GDP and the GDP in the steady state is given with equation (6):

\footnotetext{
${ }^{1}$ It means that the value of parameter $\beta_{1}$ is positive.

${ }^{2} \mathrm{~T}$ is the number of years, for which the rate of GDP growth is estimated. In case of panel models, where the period is one year, T equals to 1 .
} 


$$
\tau=-\ln (2) / \ln (\gamma)
$$

In the model of convergence described with the equation (1) the growth rate of GDP per capita depends on the fiscal policy prudence which is understood as rather restrictive fiscal policy approach and the level of investments per capita. Obtaining the positive estimate of the parameter $\alpha_{1}$ means that there is a positive influence of fiscal consolidations in a given period $t$ on the rate of growth of GDP per capita during all the period of analysis. It can be interpreted as the occurrence of non-Keynesian effects of fiscal policy for 11 analyzed countries of the European Union.

In order to estimate the parameters of model (3) the system GMM estimator was used (Blundell, Bond 1998), which is a development of first-difference GMM estimator (HoltzEakin, Newwey, Rosen 1988, Arellano, Bond 1991, Ahn, Schmidt 1995). The idea of system GMM estimator is the estimation of both equations in first differences and equations in levels. The results of two-step estimation with asymptotic standard errors are presented in the table 1.

\section{Table 1 The estimated conditional $\beta$-convergence model ${ }^{3}$}

\begin{tabular}{|c|c|c|}
\hline Parametry & Oceny & Wartość $\mathrm{p}$ \\
\hline$\gamma$ & 0,887992 & $\approx 0,000$ \\
\hline$\alpha_{1}$ & 0,00612837 & $\approx 0,000$ \\
\hline$\alpha_{2}$ & 0,134660 & $\approx 0,000$ \\
\hline \multicolumn{3}{|c|}{ Testy statystyczne } \\
\hline Sargan Test & 10,3058 & 1 \\
\hline $\mathrm{AR}(1)$ & $-2,60076$ & 0,0093 \\
\hline $\mathrm{AR}(2)$ & $-0,777938$ & 0,4366 \\
\hline
\end{tabular}

Source: own estimation based on Eurostat data and European Commission (2013).

The Sargant test enables testing of over-identifying restrictions (Blundell, Bond, Windmeijer. 2000). The obtained statistic of the test equals 10,3058 and we reject the null hypothesis. All instruments were proper. Autocorrelation of the first-differenced of disturbances was tested too. The statistic of the test for first-order serial correlation equals $-2,6007$ and we rejects the null hypothesis that there is no first-order serial correlation. The statistic of the the test for second-order serial correlation equals $-0,7779$ and we does not reject the null hypothesis of no second-order serial correlation (Baltagi 1995). It means that the system GMM estimator was consistent and efficient.

The parameter $\gamma$ is statistically significant. The estimate of the parameter $\gamma$ which is below 1 enables to estimate the value of parameter $\beta_{1}$ equal to 0,1120 and verification of the hypothesis of convergence. The average annual speed of convergence is equal to $11,88 \%$ of the distance provided similar level of investments and the degree of restrictiveness of fiscal policy for all the countries. It means that the time needed for reaching the half way between average starting output and the output in the steady state is 5,8 years.

Both parameters $\alpha_{1}$ and $\alpha_{2}$ are statistically significant. It means that variables $X_{1}$ and $X_{2}$ significantly determine the convergence process for 11 countries. The positive estimate of the parameter $\alpha_{1}$ suggests positive influence of restrictive fiscal policy and it can be interpreted as a confirmation of non-Keynesian effects of fiscal consolidations. The positive estimate of the parameter $\alpha_{2}$ means the same direction of changes between investment per

\footnotetext{
${ }^{3}$ The calculations were made with the application of the GRETL software (version 1.9.7).
} 
capita and the rate of growth per capita which is consistent with basic macroeconomic theory. It should be remembered that the speed of convergence is only conditional. It means that only provided the unified fiscal policy for all the analyzed countries and similar level of investment per capita could result in the estimated convergence process. Thus, the question concerning the possibility of obtaining similar level of investment and unified fiscal policy is an important policy problem. When the answer to this question is negative the average speed of convergence equal to $11,88 \%$ will not be reached.

\section{$4 \quad$ Qualitative Analysis of Fiscal Consolidations}

The aim of this part of the paper is to analyze the fiscal consolidations from the perspective of their Keynesian or non-Keynesian results and the question on the differences in the way both group of adjustments were implemented. The main question can be formed as follows: Were the expansive (non-Keynesian) consolidations mostly based on revenue increases or rather expenditure reductions?

Based on both demand and supply side theoretical models previously discussed one can point that the analysis should concentrate only on significantly big consolidations. Concentrating only on significantly big adjustments is also necessary as it is required to omit minor cyclical changes of budged balance and the influence of automatic stabilizers that are not the result of policy reaction. As a result for this research the significant fiscal consolidation is defined as the one when the general government primary balance improves more than 2,5\% point of GDP in one year or at least 3\% of GDP in two consecutive years. This definition is a little stricter than the one applied by Purfield in research of fiscal adjustment in transition countries, as she assumed 2\% pint of GDP improvement for one year (Purfield 2003, p. 7).

The first step of the analysis was the classification of episodes on two groups: expansionary thus non-Keynesian episodes and Keynesian consolidations. The definition of expansionary (non-Keynesian) episode is the following: the consolidation episode is expansionary when the average GDP growth during the consolidation and one year after the consolidation is above the average growth rate of potential GDP (compare Purfield 2003, p. 8). Based on that definition 14 non-Keynesian and 4 Keynesian episodes were selected, which are presented in table 2.

Table 2 Fiscal episodes fulfilling the criteria of significant consolidation

\begin{tabular}{|c|c|c|c|}
\hline \multicolumn{2}{|c|}{ Non-Keynesian consolidations } & \multicolumn{2}{|c|}{ Keynesian consolidations } \\
\hline Belgium & 2006 & Germany & 1996 \\
\hline \multirow[b]{3}{*}{ Germany } & $1999-2000$ & Luxemburg & $2006-2007$ \\
\hline & 2006-2007 & Portugal & 2011 \\
\hline & 2011 & Spain & 2000 \\
\hline \multirow[b]{2}{*}{ Ireland } & 2011 & & \\
\hline & 2012 & & \\
\hline \multirow[b]{2}{*}{ Austria } & 1998-1999 & & \\
\hline & 2007 & & \\
\hline \multirow[b]{2}{*}{ Luxemburg } & 1997 & & \\
\hline & 2000 & & \\
\hline Portugal & $2006-2007$ & & \\
\hline \multirow[b]{2}{*}{ Finland } & 1996 & & \\
\hline & 1997-1998 & & \\
\hline Spain & 2013 & & \\
\hline
\end{tabular}

Source: own compilation based on Eurostat data 2014. 
Table 3 Fundamental macroeconomic data for episodes for fiscal consolidations

\begin{tabular}{|c|c|c|c|c|c|c|c|c|c|c|c|c|c|c|c|c|c|c|}
\hline & \multirow{2}{*}{\begin{tabular}{|r|} 
Belgium \\
2006
\end{tabular}} & \multicolumn{4}{|c|}{ Germany } & \multicolumn{2}{|c|}{ Ireland } & \multicolumn{3}{|c|}{ Luxemburg } & \multicolumn{2}{|c|}{ Austria } & \multicolumn{2}{|c|}{ Portugal } & \multicolumn{3}{|c|}{ Finland } & \multirow{2}{*}{$\frac{\text { Spai }}{201}$} \\
\hline & & 1996 & 1999-2000 & 2006-2007 & 2011 & 2011 & 2012 & 1997 & 2000 & 2006-2007 & 1998-1999 & 2007 & 2006-2007 & 2011 & 1996 & $1997-1998$ & 2000 & \\
\hline Improvement of primary deficit during the episode & 2,6 & 6,1 & 3,3 & 3,5 & 3,4 & 17,6 & 6,2 & 2,5 & 2,6 & 3,8 & 3,6 & 2,8 & 3,7 & 6,7 & 3 & 4,4 & 5,1 & 4,5 \\
\hline Annual percentage change of GDP during the episode & 2,7 & 0,8 & 3,05 & 2,5 & 3,3 & 2,2 & 0,2 & 5,9 & 8,4 & 5,75 & 3,65 & 3,7 & 1,9 & $-1,3$ & 3,6 & 5,6 & 5,3 & $-1,2$ \\
\hline Annual percentage change of GDP one year after the episode & 2,9 & 1,7 & 1,5 & 1,1 & 0,7 & 0,2 & $-0,3$ & 6,5 & 2,5 & $-0,7$ & 3,7 & 1,4 & 0 & $-3,2$ & 6,2 & 3,9 & 2,3 & - \\
\hline Annual percentage change of GDP two years after the episode & 1 & 1,9 & 0 & $-5,1$ & 0,4 & $-0,3$ & & 8,4 & 4,1 & $-5,6$ & 0,9 & $-3,8$ & $-2,9$ & $-1,4$ & 5 & 5,3 & 1,8 & - \\
\hline Annual percentage change of potential GDP during the episode & 1,7 & 1,5 & 1,65 & 1,4 & 1,3 & $-0,1$ & $-0,8$ & 4,2 & 5,2 & 3,65 & 2,7 & 2 & 0,85 & $-0,5$ & 2,7 & 3,65 & 4 & $-1,4$ \\
\hline Annual percentage change of potential GDP one year after the episode & 1,8 & 1,4 & 1,5 & 1,2 & 1,4 & $-0,8$ & 0 & 4,6 & 5 & 2,3 & 2,7 & 1,6 & 0,9 & $-1,6$ & 3,4 & 4 & 3,9 & $-1,5$ \\
\hline Annual percentage change of potential GDP two years the after episode & 1,6 & 1,5 & 1,4 & 0,8 & 1,3 & 0 & 1,1 & 5,7 & 4,7 & 0,9 & 2,4 & 0,9 & $-0,2$ & $-1,2$ & 3,9 & 4 & 3,4 & \\
\hline Annual change of total revenues (\% of GDP) during the episode & 0,8 & 0,3 & 0,25 & 0,05 & 0,6 & $-0,9$ & 0,5 & 2 & 1 & $-0,3$ & $-0,25$ & 1 & 0,5 & 3,4 & 1,3 & $-1,05$ & 2 & 0,6 \\
\hline Annual change of total expenditures (\% of GDP) during the episode & 0,3 & $-5,8$ & $-1,45$ & $-0,9$ & $-2,7$ & $-18,4$ & $-4,5$ & $-0,4$ & $-1,6$ & $-2,6$ & $-0,05$ & $-0,5$ & $-1,1$ & $-2,2$ & 0,5 & $-3,6$ & $-3,4$ & -3 \\
\hline
\end{tabular}

Source: own compilation based on Eurostat data 2014 and European Commission (2013). 
Table 3 presents fundamental macroeconomic data for all analysed episodes of fiscal consolidations. First of all, for 15 analysed episodes only in case of two Portugal in 2011 and Spain in 2013 one could see negative GDP change, which can be attributed to difficult condition of both economies after global financial crisis from the year 2008. In case of composition of episodes, most of them have mixed character with some increases of revenues and cuts of expenditures. Only two episodes - Belgium in 2006 and Finland in 1996 an increase in expenditures and more than proportional increase in revenues could be seen. Three episodes Ireland in 2011, Austria in 1998-1999 and Finland 1in 997-1998 were based on decrease in both revenues and expenditures.

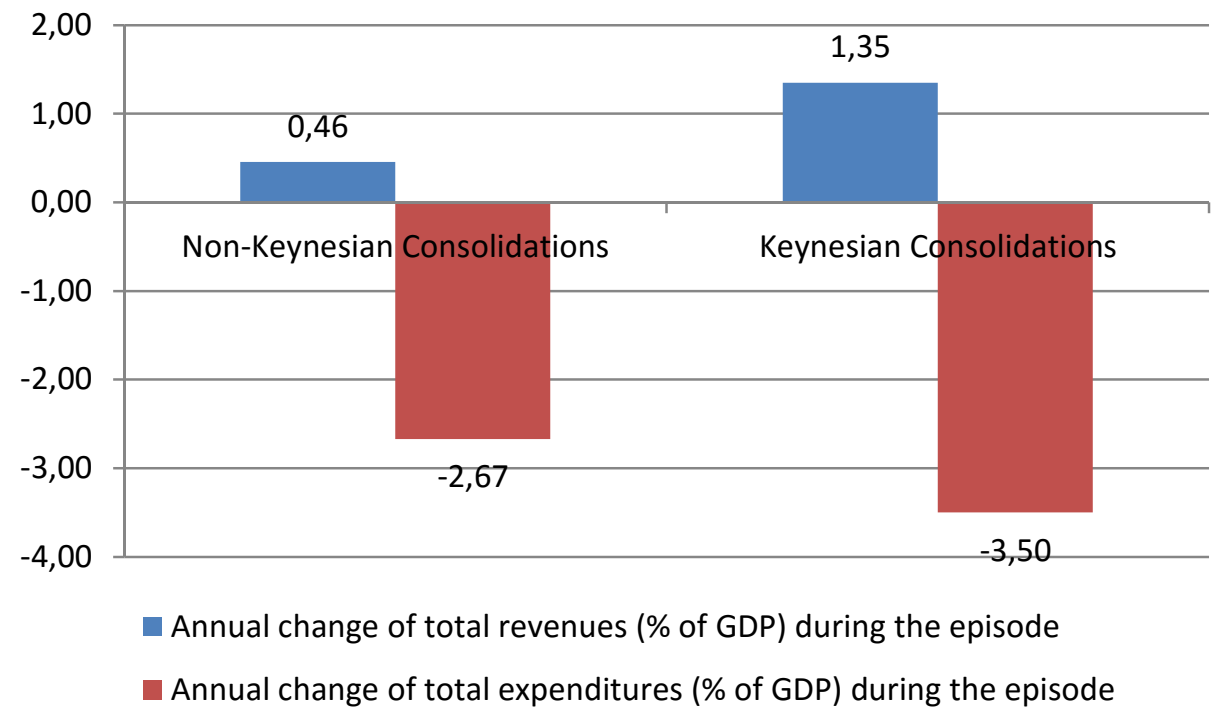
Figure 1 Average annual changes of government budget revenues and expenditures for non-Keynesian and Keynesian episodes of fiscal consolidations Source: own estimation based on Eurostat data 2014.

Figure 1 presents an average annual changes of government budget revenues and expenditures for the group of non-Keynesian and Keynesian episodes of fiscal consolidations. The average change of annual expenditures in case of non-Keynesian consolidations was $-2,67 \%$ of GDP whereas for group of Keynesian episodes it was $-3,5 \%$. However, a serious difference can be seen in case of annual change of revenues. For the group of expansionary episodes the average increase of revenues was 3 times lower than in the group of Keynesian consolidations, which can suggests that expansionary episodes were based on the tax increases to much lesser extent than the non-expansionary episodes. These results are conducive to the research of Alesina and Ardagna (2009) for OECD countries in the years 1970-2007.

First of all, in case of interpretation of the above presented results it must be remembered that this kind of qualitative analysis has serious methodological drawback. The main problem is the small number of examined consolidations, in that case especially the number of Keynesian episodes is not satisfactory. Then all the qualitative analyzes are quite sensitive to changes of definitions of significant and expansionary episodes. Thus this results can be only treated as a voice in the discussion, definitely not as prevailing argument.

\section{Conclusion}

The end of the $X X^{\text {th }}$ and the beginning of the first decade of current century made a period of significant deleverage and public finance stabilization, which was in part the element of process of the Eurozone creation. That situation was changed with the global financial crisis 
of the year 2008 that resulted in the significant increase of government debt of highly developed countries.

The conducted econometric analysis gives significant arguments on the thesis that last decades in case of 11 analyzed countries made a period of conditional $\beta$-convergence where prudent fiscal policy was the significant convergence factor. Thus, the analysis based on convergence framework can be interpreted as an argument supporting the thesis on the possibility of non-Keynesian effects in case of significant fiscal consolidations. In the same time the analysis can give some argument that the future deleverage process, which will be probably necessary for keeping long term growth perspective in Europe, in case of proper construction of consolidation programs does not have to be a short term growth obstacle. In spite of its serious methodological drawback, the qualitative analysis showed that in case of the group of expansionary episodes the increases of taxes and revenues were much lower than in case of typical Keynesian consolidations. This can be a factor to consider in the context of plans for future effort to deleverage and stabilize fiscal systems of European Countries.

The next steps concerning future research in the field should be coverage of wider group of countries such as examining whole countries of current euro area and in the end all countries of European Union. The next steps should be also more detailed concentration on the fiscal transitions mechanism that accompanied non-Keynesian and typical Keynesian consolidations in European Union.

\section{References}

Ahn, S.C., Schmidt, P., 1995. Efficient estimation of models for dynamic panel data, Journal of Econometrics, vol. 68, pp. 5-27.

Alesina, A., and Ardagna, S., 1998. Fiscal Adjustments. Why They Can Be Expansionary. Tales, of Fiscal Adjustment. Economic Policy, 13(27).

Alesina, A., and Ardagna, S., 1998. Tales of Fiscal Adjustments, Economic Policy. October, pp. 489-545.

Alesina, A., and Ardagna, S., 2009. Large Changes in Fiscal Policy: Taxes versus Spending. NBER Working Paper Series, Working Paper No. 15438.

Alesina, A., Ardagna, S., Perotti, R., Schiantarelli, F., 1999. Fiscal Policy, Profits and Investment. NBER Working Papers, Working Paper 7207.

Alesina, A., Perotti, T., 1997. The Welfare State and Competitiveness. American Economic Review, 87(5).

Arbia, G., 2006. Spatial Econometrics, Springer-Verlag, Berlin Heidelberg.

Arellano, M., Bond, S., 1991, Some tests of specification for panel data: Monte Carlo evidence and an application to employment equation, Review of Economic Studies, vol. 58, pp. 277-297.

Balcerzak, A.P., Rogalska, E., 2014. Crowding Out and Crowding in within Keynesian Framework. Do We Need Any New Empirical Research Concerning Them? Economics \& Sociology, 7(2), pp. 80-93. DOI: 10.14254/2071-789X.2014/7-2/18.

Baltagi, B. H.,1995. Econometric analysis of panel data, John Wiley\&Sons Ltd., Chichester. 
Barro, R.J., Sala-I-Martin, X., 1991. Convergence across States and Regions, Brookings Papers on Economic Activity.

Barro, R.J., Sala-I-Martin, X., 1992. Convergence, Journal of Political Economy, vol. 100, pp. 223-251.

Barro, R.J., Sala-I-Martin, X., 1995. Economic Growth Theory, McGraw-Hill, Boston.

Baumol, W.J., 1986. Productivity Growth, Convergence and Welfare: What the Long Run Data Show, American Economic Review, vol.76, pp. 1072-1085.

Bernard, A.B., Durlauf, S.N., 1995. Convergence in International Output, Journal of Applied Econometrics, vol. 10, pp. 97-108.

Blundell, R., Bond, S., 1998. Initial conditions and moment restrictions in dynamic panel data model, Econometric Review, vol. 19(3), pp. 321-340.

Blundell, R., Bond, S., Windmeijer, F., 2000, Estimation in dynamic panel data models: improving on the performance of the standard GMM estimator, in: B. Baltagi, Nonstationary Panels, Panel Cointegration and Dynamic Panels, Elsevier Science.

Bond, S., Hoeffler, H., Temple, J., 2001. GMM estimation of empirical growth models, Discussion Paper no. 3048, Centre for Economic Policy Research.

Caselli, F., Esquivel, G., Lefort, F., 1996. Reopening the Convergence Debate: A new look at Cross-Country Growth Empirics, Journal of Economic Growth, vol. 1, pp. 363-390.

Ciołek, D., 2005. Konwergencja do Unii Europejskiej krajów w okresie transformacji, doctoral thesis, Uniwersytet Gdański, Gdańsk.

Durlauf, S.N., Johnson, P.A., 1995. Multiple Regimes and Cross-Country Growth Behaviour, Journal of Applied Econometrics, vol. 10, pp. 365-384.

Eichenbaum, M., 1997. Some Thoughts on Practical Stabilization Policy, American Economic Review, 87(2).

European Commission, 2013. General Government Data. General Government Revenue, Expenditure,

Balances and Gross Debt, Part II: Tables by Series, Spring.

Evans, P., Karras, G., 1996. Convergence Revisited, Journal of Monetary Economics, vol. 37, pp. 249-265.

Giavazzi, F., Pagano, M., 1990. Can Severe Fiscal Contractions Be Expansionary? Tales of Two Small European Countries. in: O. Blanchard, S. Fisher, Macroeconomics Annual 1990, MIT Press.

Holtz-Eakin, D., Newwey, W., Rosen, H., 1988. Estimating vector autoregressions with panel Data, Econometrica, vol. 56, pp. 1371-1395.

Islam, N., 1995. Growth Empirics: A Panel Data Approach, Quarterly Journal of Economics, vol. 110, pp. 1127-1170.

Lane, P.R., Perotti, R., 2001. The Importance of Composition of Fiscal Policy: Evidence from Different Exchange Rate Regimes. Trinity College Dublin, Department of Economics, Trinity Economics Papers, Number 200116. 
Le Gallo, J., Ertur C., 2003. Exploratory Spatial Data Analysis of the Distribution of Regional per Capita GDP in Europe, 1980-1995, Papers in Regional Science, Vol. 82, Iss. 2, pp. 175201.

Levine, R., Renelt, D., 1992. A sensitivity analysis of cross-country growth regressions, American Economic Review, vol. 82, pp. 942-963.

Mankiw, N.G., Romer, D., Weil D.N., 1992. A Contribution to the Empirics of Economic Growth, Quarterly Journal of Economics, vol. 107, pp. 407-437.

Perotti, R., 1999. Fiscal Policy in good Times and bad. The Quarterly Journal of Economics, November.

Purfield, C., 2003. Fiscal Adjustment in Transition Countries: Evidence from the 1990s. IMF Working Paper, WP/03/36.

Quah, D., 1993a. Empirical Cross-section Dynamics in Economic Growth, European Economic Review, vol. 37, pp. 426-434.

Quah, D., 1993b. Galton's Fallacy and Tests of the Convergence Hypothesis, Scandinavian Journal of Economic, vol. 95, pp. 427-443.

Quah, D., 1996a. Empirics for Economic Growth and Convergence, European Economic Review, vol. 40, pp.1353-1375.

Quah, D., 1996b. Twin Peaks: Growth and Convergence in Models of Distribution Dynamics, Economic Journal, vol. 106, pp. 1045-1055.

Rey, S.J., Montouri, B.D., 1999. U.S. Regional Income Convergence: a Spatial Econometric Perspective, Regional Studies, vol. 33, pp. 145-156.

Rogalska, E., 2012. Efektywność stymulacyjnej polityki fiskalnej państwa w warunkach kryzysu zaufania budżetowego. Oeconomia Copernicana, 4.

Rzońca A., Varoudakis A., 2007. The Quality of Fiscal Adjustments in Transition Economies. Bank i Kredyt, 7.

Rzońca, A., Ciżkowicz, P., 2005. Non-Keynesian Effects of Fiscal Contraction in New Member States. European Central Bank, Working Papers Series, No. 519/September.

Sala-I-Martin, X., 1996a. Regional Cohesion: Evidence and Theories of Regional Growth and Convergence, European Economic Review, vol. 40, pp. 1325-1352.

Sala-I-Martin, X., 1996b. The Classical Approach to Convergence Analysis, Economic Journal, vol. 106, pp. 1019-1036. 